\title{
Myotonia Congenita
}

National Cancer Institute

\section{Source}

National Cancer Institute. Myotonia Congenita. NCI Thesaurus. Code C84912.

A genetic congenital neuromuscular disorder affecting the skeletal muscles. It is caused by mutations in the chloride channel gene (CLCN1 gene). It is characterized by muscle stiffness, hypertrophy, pain, and cramping. 